pp. $195-202$

\title{
Foreign Trade and Marketing Processes in the Context of Sustainable Development
}

\author{
Malakhova T.S. ${ }^{1}$, Dubinina M.A.. ${ }^{2}$, Maksaev A.A. ${ }^{3}$, Fomin R.V. ${ }^{4}$ \\ Abstract:
}

Purpose: The article aims to study foreign economic and trade relations between the countries of Central and Eastern Europe, the CIS and the Western European countries. In addition, the study improves forms of foreign economic cooperation between the countries and suggests the stages of its implementation in the integration group.

Design/Methodology/Approach: Central and Eastern European countries are experiencing the increase and acceleration of the labour migration to Western European countries, which has a negative impact on their medium-and long-term development. As a theoretical and methodological basis, the article uses historical-logical, dialectical principles and contradictions, the method of the scientific abstraction. The process-system approach, which was used in the study of foreign economic relations between the partner countries, gained special importance in the argument of the need to implement stages.

Findings: Authors presented the form of the foreign economic cooperation between the countries as the geostrategic economic block and the stages of its implementation. As the study shows, these stages will help to smooth out the economic inequality between the Central and Eastern regions of Europe and Western European countries.

Practical implications: In practice, authors investigate the phased implementation of the geostrategic economic bloc form, which will reduce inequality between the partner countries of the European Union.

Originality/Value: The economic inequality between developed and developing countries of the European Union is increasing every year, which can lead to the transformation of the integration group, so it is necessary to develop new forms and mechanisms of foreign economic relations between the partner countries.

Keywords: Integration, foreign economic relations, European Union, geostrategic economic bloc, economic inequality.

JEL Code: F02, F15, F63.

Paper type: Research article: Foreign Trade.

\footnotetext{
${ }^{1}$ Associate Professor of the World Economy and Management Department, Kuban State University, Krasnodar; applicant for Doctor's Degree of the World Economy Department of Russian University of Economics named after G.V.Plekhanov, malakhovats@mail.ru ${ }^{2}$ Associate Professor of the Trade and Public Catering Department, Krasnodar branch of the Russian Univercity of Economics named after G.V. Plekhanov, dubinina@mail.ru ${ }^{3}$ Associate Professor of the Managemen and Trade Deal Department, Krasnodar Cooperative Institute, Krasnodar, maksaev@mail.ru ${ }^{4}$ Post graduate of the Economics and Modeling of Production Processes Department, Belgorod State Research Univercity, Belgorod, fomin@mail.ru
} 


\section{Introduction}

The position of Central and Eastern European countries in global economic relations is determined by the export-import structure of their foreign trade, which affects the economic development of the region. The increasing role of foreign trade as an engine of the economic growth in the countries of Central and Eastern Europe is associated with the development of export-oriented high-tech production. It is known that engineering plays a leading role in this process. The basis of machine-building exports of Central and Eastern Europe remains at low level. In 2018, the region had a surplus of trade in machinery, equipment and vehicles, which was provided by the Czech Republic, Hungary, Poland, Romania, Slovenia and Slovakia.

However, there are both internal and external problems in the region related to the interaction with some countries and regions of the world. The desire of this region to activate its own capabilities to accelerate the economic development is faced with limited investment flows compared to Western European countries and the level of their economies competitiveness. The involvement in the sanctions policy of the West complicates traditional ties, which exacerbates problems of Central and Eastern Europe in the world market. On this basis, it is necessary to study peculiarities of foreign trade and economic relations of Central and Eastern European individual countries, including the CIS countries, and to propose a new form of the foreign economic cooperation between the partner countries.

\section{Materials and Methods}

The works of the following scientists are devoted to the evolution of foreign economic and trade relations between countries, as well as the positions of some states in the world economy: B. Balassa (1982), J. Galbraith (1951), J. Nehru (1961), F. Pazos (1953), R. Prebish (1981), Ya. Tinbergen (1952), A. Frank (1980) and many others.

Investigations by the Swedish economist G. Myrdal (1956), who proposed in the middle of the XXth century the international economic integration concept is very interesting. The basic principles and mechanisms of its development were mainly projected on Western European countries, but in modern conditions its fundamental groundwork needs the further improvement in the context of the turbulent state of the European Union. The process-system approach, which was used in the analysis of the main macroeconomic indicators of the Central and Eastern European countries and the identification of key problems and contradictions of their further development, is very important for creating the new form of the foreign economic cooperation between the countries.

\section{Results}

Under the sanction's regime, there are significant transformations in the European Union and Russia, in their foreign trade and economic relations. The study of foreign 
economic relations of Central and Eastern Europe with some countries and regions of the world are of interest. Table 1 presents the main indicators of individual Central and Eastern European countries foreign trade from 2014 to 2017 (exports, imports, foreign trade turnover, foreign trade balance). It must be admitted that we are conducting the analysis of those Central and Eastern European countries that operate in the European Union. Thus, the foreign trade balance is one of the most important characteristics of foreign trade activity of any state. During the analyzed period in 5 countries of 10 Central and Eastern European countries operating in the European Union, there is a negative balance, namely in Bulgaria, Latvia, Lithuania, Romania, Estonia. For example, in 2017, exports from Bulgaria amounted to 26.6 billion EUR, and imports amounted to -30.2 billion EUR. The foreign trade balance amounted to -3.6 billion EUR. In 2014, the foreign trade balance was - 4.1 billion EUR, in 2015 - 3.4 billion EUR, in 2016 - 2.2 billion EUR, in 2017 - 3.6 billion EUR (Table 1).

Table 1. Key foreign trade indicators of Central and Eastern European countries (exports, imports, foreign trade volume, balance) (billion EUR) (FT, 2018)

\begin{tabular}{|l|l|l|l|l|l|l|}
\hline Countries & $\begin{array}{l}\text { Exports/ } \\
\text { Imports } \\
2014\end{array}$ & $\begin{array}{l}\text { Foreign } \\
\text { trade } \\
\text { volume, } \\
2014\end{array}$ & $\begin{array}{l}\text { Balance, } \\
2014\end{array}$ & $\begin{array}{l}\text { Exports/ } \\
\text { Imports } \\
2017\end{array}$ & $\begin{array}{l}\text { Foreign } \\
\text { trade } \\
\text { volume, } \\
2017\end{array}$ & $\begin{array}{l}\text { Balance, } \\
2017\end{array}$ \\
\hline Bulgaria & $22,0 / 26,1$ & 48,1 & $-4,1$ & $26,6 / 30,2$ & 56,8 & $-3,6$ \\
\hline Hungary & $83,3 / 79,0$ & 162,3 & 4,3 & $100,6 / 95,0$ & 195,6 & 5,6 \\
\hline Latvia & $11,013,3$ & 24,3 & $-2,3$ & $12,3 / 14,9$ & 27,2 & $-2,6$ \\
\hline Lithuania & $24,4 / 25,9$ & 50,3 & $-1,5$ & $26,4 / 28,5$ & 54,9 & $-2,1$ \\
\hline Poland & $165,7 / 168,4$ & 334,1 & $-2,7$ & $204,4204,0$ & 408,4 & 0,4 \\
\hline Romania & $52,5 / 58,6$ & 111,1 & $-6,1$ & $62,6 / 75,6$ & 138,2 & $-13,0$ \\
\hline Slovakia & $65,1 / 61,7$ & 126,8 & 3,4 & $74,8 / 73,7$ & 148,5 & 1,1 \\
\hline Slovenia & $27,1 / 25,6$ & 52,7 & 1,5 & $34,0 / 31,9$ & 65,9 & 2,1 \\
\hline Czechia & $131,8 / 116,2$ & 248,0 & 15,6 & $159,5 / 143,4$ & 302,9 & 16,1 \\
\hline Estonia & $12,1 / 13,8$ & 25,9 & $-1,7$ & $12,9 / 14,7$ & 27,6 & $-1,8$ \\
\hline
\end{tabular}

In Latvia and Lithuania, the situation is approximately the same. Imports to Latvia in 2017 compared to 2014 increased by 1.6 billion EUR. In Lithuania, this figure also increased by 2.6 billion EUR. In Romania and Estonia, there is also the import dependence tendency in relation to foreign goods, which leads to the degradation of national industries. In general, the negative balance of foreign trade means that the value of goods imported from abroad is greater than that exported from the country. In addition, the negative trade balance means little demand for goods and services in the global and regional markets. It can be stated that the long-term negative balance in the country has a negative impact on the national economy.

Since 2014 to 2017 only Hungary, Slovakia, Slovenia and the Czech Republic had a trade surplus. Thus, exports from Hungary in 2017 amounted to 100.6 billion EUR, and imports for the study period amounted to 95.0 billion EUR, therefore, the foreign 
trade balance was positive (5.6 billion EUR). If we examine these indicators from 2014, it can be noted that exports from countries are increasing every year (in 2014 83.3 billion EUR, in 2015 - 88.8 billion EUR, in 2016 - 92.1 billion EUR). In Slovakia and Slovenia, exports from countries are also increasing every year. In 2017 exports from Slovakia amounted to 74.8 billion EUR, and from Slovenia 34.0 billion EUR. As for the Czech Republic, for the analyzed period also revealed the positive foreign trade balance (in 2014 it was 15.6 billion EUR, in 2015 it was 14.9 billion EUR, in 2016 it was 17.7 billion EUR, in 2017 it was 16.1 billion EUR). Of course, the Central and Eastern European countries are active participants both in the European market and in the world. However, it is interesting to study their foreign trade and economic relations with the CIS countries (Table 2).

Table 2. CIS trade with individual countries Central and Eastern Europe (billion US dollars) (FT, 2018)

\begin{tabular}{|c|c|c|c|c|c|c|c|c|}
\hline \multirow[b]{2}{*}{ Countries } & \multicolumn{4}{|c|}{$\begin{array}{l}\text { Exports of the CIS countries to the } \\
\text { Central and Eastern European } \\
\text { individual countries }\end{array}$} & \multicolumn{4}{|c|}{$\begin{array}{l}\text { Imports of the CIS countries } \\
\text { from the Central and Eastern } \\
\text { European individual countries }\end{array}$} \\
\hline & $\begin{array}{l}2 \\
0 \\
0 \\
5\end{array}$ & $\begin{array}{l}2 \\
0 \\
1 \\
7\end{array}$ & $\begin{array}{l}\text { Averag } \\
\text { e } \\
\text { annual } \\
\text { growth } \\
\text { rate } \\
2017 \text { as } \\
\% \text { of } \\
2005\end{array}$ & $\begin{array}{l}\text { Share in } \\
\text { total exports } \\
\text { of the CIS } \\
\text { countries to } \\
\text { the Central } \\
\text { and Eastern } \\
\text { Europe } \\
\text { individual } \\
\text { countries in } \\
2017, \%\end{array}$ & $\begin{array}{l}2 \\
0 \\
0 \\
5\end{array}$ & $\begin{array}{l}2 \\
0 \\
1 \\
7\end{array}$ & $\begin{array}{l}\text { Averag } \\
\text { e } \\
\text { annual } \\
\text { growth } \\
\text { rate } \\
2017 \text { as } \\
\% \text { of } \\
2005\end{array}$ & $\begin{array}{l}\text { Share in total } \\
\text { exports of } \\
\text { the CIS } \\
\text { countries to } \\
\text { the Central } \\
\text { and Eastern } \\
\text { Europe } \\
\text { individual } \\
\text { countries in } \\
2017, \%\end{array}$ \\
\hline Bulgaria & 2,6 & 4,0 & 3,7 & 7,7 & 0,5 & 1,0 & 6,6 & 3,3 \\
\hline Hungary & 5,9 & 4,7 & $-1,8$ & 9,0 & 1,9 & 3,6 & 5,4 & 11,9 \\
\hline Latvia & 2,0 & 5,5 & 8,7 & 10,6 & 0,5 & 0,7 & 2,8 & 2,3 \\
\hline Lithuania & 4,6 & 4,7 & 0,1 & 9,0 & 1,0 & 1,8 & 5,2 & 6,0 \\
\hline Poland & 10,9 & 16,2 & 3,3 & 31,2 & 5,0 & 10,3 & 6,2 & 34,1 \\
\hline Romania & 4,3 & 5,0 & 1,3 & 9,6 & 1,0 & 3,0 & 9,9 & 9,9 \\
\hline Slovakia & 3,8 & 4,0 & 0,4 & 7,7 & 0,9 & 2,7 & 9,6 & 8,9 \\
\hline Slovenia & 0,2 & 0,3 & 5,2 & 0,6 & 0,7 & 1,3 & 5,8 & 4,3 \\
\hline Czechia & 4,3 & 5,4 & 2,0 & 10,4 & 1,8 & 4,9 & 8,5 & 16,2 \\
\hline Estonia & 2,5 & 2,1 & $-1,4$ & 4,0 & 0,4 & 0,9 & 7,2 & 3,0 \\
\hline Total & 41,1 & 51,9 & 2,15 & 100 & 13,7 & 30,2 & 6,72 & 100 \\
\hline
\end{tabular}

Table 2 presents data on CIS trade with individual Central and Eastern European countries. If we analyze the trade of the CIS countries with individual Central and Eastern European countries, it should be noted that exports from 2005 to 2017 increased from $\$ 41.1$ billion to $\$ 51.9$ billion. The increase in exports is observed in almost all the Central and Eastern European countries such as Bulgaria, Latvia, Poland, Czech Republic, etc. So, in 2005, exports to Bulgaria from the CIS countries 
amounted to $\$ 2.6$ billion, and in 2017 amounted to Us $\$ 4.0$ billion. Also, the increase in exports from the CIS countries is in Latvia (in 2005 it amounted to 2.0 billion dollars), in 2017 it amounted to 5.5 billion.), which is a positive trend for the medium and long term.

If we analyze the foreign trade relations of the CIS countries with Poland, it should be noted that this country is the largest partner of the organization. In 2005, exports to Poland amounted to $\$ 10.9$ billion, and in 2017 it amounted to $\$ 16.2$ billion. Also, the increase in exports from the CIS countries is observed in the Czech Republic (in 2005 it amounted to $\$ 4.3$ billion). In 2017 it amounted to $\$ 5.4$ billion). A slight increase in exports is observed in Lithuania, Romania, Slovakia, Slovenia.

In general, the increase in exports from the CIS to individual Central and Eastern European countries only indicates that it is necessary to further strengthen and develop foreign trade and economic relations between the countries. However, there are countries to which the CIS countries began to reduce exports. These are, first, Hungary and Estonia. In 2005, exports to Hungary amounted to \$ 5.9 billion, and in 2017 it amounted to $\$ 4.7$ billion. As for Estonia, exports to this country also decreased from $\$ 2.5$ billion in 2005 to $\$ 2.1$ billion in 2017 .

As for the share in the total exports of CIS countries to individual Central and Eastern European countries in 2017, it was $31.2 \%$ in Poland, $10.6 \%$ in Latvia, $10.4 \%$ in the Czech Republic, 9.6\% in Romania, 9.0\% in Lithuania, etc. The lowest figure is in Estonia it is $4.0 \%$ and Slovenia - 0.6\%. The increase in export operations in 2017 compared to 2005 took place almost in all the countries except Hungary $(-1.8 \%)$ and Estonia (-1.4\%). If we analyze imports of CIS countries from individual Central and Eastern European countries, it should be noted that this figure increased significantly in Poland, the Czech Republic, Romania, Slovakia, etc. In general, imports increased from 2005 to 2017 from $\$ 13.7$ billion to $\$ 30.2$ billion in 2017. It is possible to speak about great interest in foreign trade relations between the CIS countries and individual Central and Eastern European countries. For example, Poland exported \$ 5.0 billion worth of goods to CIS countries in 2005, and in 2017 by $\$ 10.3$ billion worth of goods. If we examine exports from the Czech Republic to the CIS countries, it amounted to $\$ 1.8$ billion in 2005 , and in 2017 \$ it amounted to 4.9 billion.

The positive trend is also observed from Romania and Slovakia. Exports from these countries in 2005 amounted to $\$ 1.0$ billion and $\$ 0.9$ billion, and in 2017 amounted $\$$ 3.0 billion and $\$ 2.7$ billion. As for Estonia and Latvia, exports from these countries did not increase significantly during the analyzed period (in 2005, exports from Estonia amounted to $\$ 0.4$ billion), from Latvia it amounted to $\$ 0.5$ billion, and in 2017 amounted to 0.9 and 0.7 billion respectively.)

If we analyze the total imports share of the CIS countries from individual Central and Eastern European countries, in Poland it was 34.1\%, in the Czech Republic it was $16.2 \%$, in Hungary it was $11.9 \%$, in Romania it was $9.9 \%$, in Slovakia it was $8.9 \%$, 
etc. The lowest figure is in Latvia 2.3\%, and in Estonia 3.0\%. The increase in import operations in 2017 compared to 2005 occurred in all analyzed countries, especially in Romania (9.9\%), Slovakia (9.6\%), Czech Republic (8.5\%), etc.

Nevertheless, if we study the foreign trade and economic relations of individual Central and Eastern European countries with the developed countries of the European Union, problems and contradictions between them are growing and increasing every year. There are at least five reasons that can lead to the transformation of the entire European Union (Malakhova and Kolesnikov, 2018):

1. Full liberalization in the movement of goods, services, capital and labours within the integration has led to imbalances in the development and location of production, deepening income inequality.

2. Differences in the sectoral structures of the economies of the member states of the European Union.

3. The concentration of TNC and TNB is predominantly in the developed countries of the European Union.

4. The introduction of the single currency within the European Union has led to the dependence of the periphery countries on the monetary policy of the core countries.

5. The increase and acceleration of the labour migration from periphery to core countries.

Therefore, in order to eliminate these problems and contradictions, a form of foreign economic cooperation between the countries is proposed. It is a geostrategic economic bloc. The geostrategic economic bloc (BBB) is the economic cooperation forum between developed and developing countries which makes it possible to reduce their economic disparities in the Association, to protect the position of the peripheral countries through the application of certain stages, which in turn make it possible to deepen and develop their backbone industry that will allow, first, to reduce the backlog of the peripheral countries from the avant-garde, and second, to keep key sectors of the peripheral countries of the third, to strengthen the positions of peripheral countries in foreign trade and economic relations with developed countries (Malakhova, 2015).

The main stages of the implementation of the foreign economic cooperation form of the partner countries as the geostrategic economic block are presented in Figure 1. 
Figure 1. Stages of the implementation of the foreign economic cooperation forum between the partner countries of the geostrategic economic bloc (compiled by the authors)

Stages of the implementation of the f foreign economic cooperation forum between the partner countries of the geostrategic economic bloc

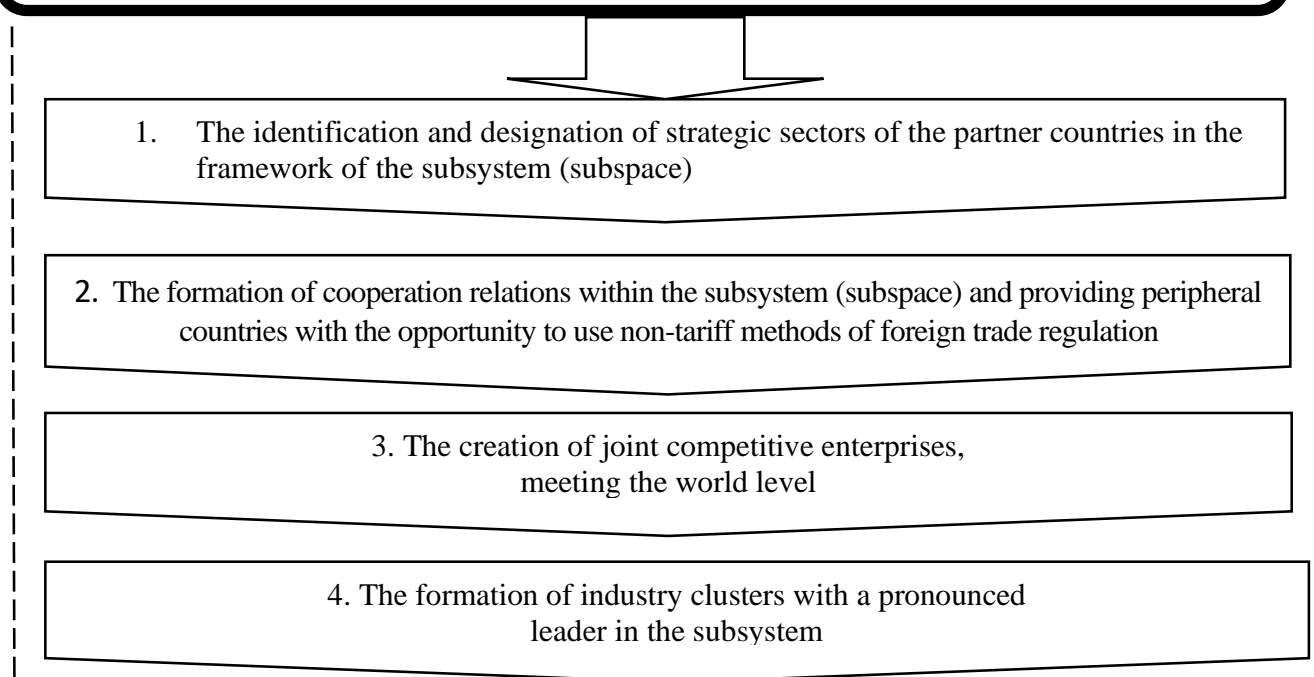

5. The creation of a supranational framework in the form of competitive enterprises on a regional scale

\section{Discussion}

According to almost all leading countries, in conditions of the liberalization of foreign economic and trade relations, no country alone can successfully develop, as well as cope with structural problems. Developed countries (core countries), when combined with partner countries (periphery), emphasize complementarity and mutual benefit, considering individual national interests.

In order to reduce imbalances between developed and developing countries, where the vanguard country plays a fundamental role, it is necessary to put into practice the geostrategic economic bloc as the foreign economic interaction form. They can be applied to Central and Eastern European countries in cooperation with Western European countries in order to eliminate economic inequality in the integration group. 


\section{Conclusion}

The article highlights and studies the problems and contradictions in the interaction of Central and Eastern Europe with the developed countries of the European Union: the complete liberalization in the movement of goods, services, capital and labour due to the integration has led to imbalances in the development and placement of production, deepening income inequality; differences in the sectoral structures of the economies of the European Union member states; the concentration of TNC and TNB mainly in the developed countries of the European Union; the single currency introduction within the European Union has led to the dependence of the peripheral countries on the monetary policy of the core countries; the increase and acceleration of the labour migration from the periphery to the core countries, etc. If these problems are not eliminated in the nearest future, the European Union can expect significant internal changes.

The foreign economic interaction form as the geostrategic economic block and the main stages of its implementation are proposed in this article. As the study shows, these stages will help to smooth the inequality between the Central and Eastern European countries and Western European countries within the integration group.

\section{References:}

Balassa, B. 1982. The Theory of Economic Integration. Greenwood Press Reprint. Frank, A.G. 1980. Crisis in the world economy. Holmes \& Meier Publishers.

FT. 2018. Foreign Trade of the CIS and EU countries. Interstate Statistical Committee of the CIS, Moscow.

Galbraith, J.K. 1951. Conditions for Economic Change in Under-Developed Countries.

Malakhova, T.S. 2015. The crisis of the global economy: trends and contradictions. Krasnodar, Kuban State University, 79-80.

Malakhova, T.S., Kolesnikov, N.P. 2019. Trends and contradictions of the global economy crisis and transformation of the world financial institutions. European Journal of Economics and Management Sciences, 1, 38-41.

Myrdal, G. 1956. An International Economy: Problems and Prospects. New York, Harper \& Brothers publishers.

Nehru, J. 1961. Strategy of the Third Plan. Delhi, Government of India, Ministry of Information and Broadcasting.

Pazos, F. 1953. Economic Development and Financial Stability. Staff Papers. International Monetary Fund, October.

Prebish, R. 1981. Capitalismo periferico Crisis y transformatico. Fondo de Cultura Economica, Mexico.

Tinbergen, J. 1952. On the Theory of Economic Integration. Les Cahiers de Bruges (Bruges Quarterly). 